\title{
Epicurean Wills, Empty Hopes, and the Problem of Post Mortem Concern
}

\section{Bill Wringe}

To cite this article: Bill Wringe (2016) Epicurean Wills, Empty Hopes, and the Problem of Post Mortem Concern, Philosophical Papers, 45:1-2, 289-315, DOI: 10.1080/05568641.2016.1187483

To link to this article: https://doi.org/10.1080/05568641.2016.1187483

册 Published online: 05 Jul 2016.

Submit your article to this journal $₫$

山 Article views: 40

Q View related articles $\square$

View Crossmark data ¿

Citing articles: 1 View citing articles $\longleftarrow$ 


\title{
Epicurean Wills, Empty Hopes, and the Problem of Post Mortem Concern Bill Wringe
}

\begin{abstract}
Many Epicurean arguments for the claim that death is nothing to us depend on the 'Experience Constraint': the claim that something can only be good or bad for us if we experience it. However, Epicurus' commitment to the Experience Constraint makes his attitude to will-writing puzzling. How can someone who accepts the Experience Constraint be motivated to bring about post mortem outcomes?

We might think that an Epicurean will-writer could be pleased by the thought of his/her loved ones being provided for after his/her death. Warren has argued that this does not dissolve the puzzle, since it involves a hope which the Epicurean should take to be empty just as the fear of death is empty. However, if it is a necessary condition of an emotion's being empty that it involve accepting a claim which is not only false but also harmful it is not clear that this hope is indeed 'empty': there is a crucial disanalogy between fearing death and hoping for the prosperity of one's children here. And if emptiness does not require harmfuless, an Epicurean has no need to rid themselves of the emotion.
\end{abstract}

\section{I: Introduction}

Epicurus and his followers are well-known for thinking that our deaths cannot harm us: for an Epicurean, death can be 'nothing to us'. ${ }^{1}$ Many of their arguments for this claim seem to depend on their acceptance of what one might call the Experience Constraint'-the claim that something can only be good or bad for us if we experience it-together with their belief that we have no post mortem experiences. ${ }^{2}$

The fact that Epicurus accepted the Experience Constraint makes the fact that he wrote a will somewhat surprising. As Cicero points out in $\mathrm{On}$

1 As a referee for Philosophical Papers pointed out, we might even go so far as to say that freeing us from the fear of death by persuading us of this claim is central to their philosophical project.

2 See Warren Facing Death 2004.

Routledge

Taylor \& Francis Group
ISSN 0556-8641 print/ISSN 1996-8523 online (C) 2016 The Editorial Board, Philosophical Papers DOI: $10.1080 / 05568641.2016 .1187483$

http://www.tandfonline.com

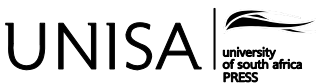


Moral Ends, it is hard to see what could have motivated him to do so. ${ }^{3}$ We might suspect that Cicero's point depends either on a misunderstanding of Epicurus' view, or on some kind of polemical misrepresentation of it. However, James Warren has argued that his complaint can be backed by sound arguments. The underlying point can be expressed either as one about rationality or about motivation. If one thinks that no post mortem outcomes have value then it is difficult to see what could motivate one to pursue them. It is also difficult to see how actions taken in pursuit of such ends could be rational. ${ }^{4}$

It would be a mistake to regard this issue as an arcane problem, of interest only to scholars of Hellenistic philosophy. Many people find the 'Experience Constraint' intuitively plausible; believe, like Epicureans, that there is no post mortem experience; but nonetheless have projects whose success or failure will only be apparent after their death. These people have a problem which is analogous to of the Epicurean willwriter. We might call this the 'Problem of Post Mortem Concern.'

I shall argue that the problem Cicero raises can be solved without abandoning the Experience Constraint. I shall also argue that my solution generalizes into a solution to the 'Problem of Post Mortem Concern.' Unsurprisingly, I disagree with Warren's assessment of the argument which we both take to underlie Cicero's complaint. I shall claim that although an Epicurean should regard fears about post mortem events as 'empty', it is reasonable for him or her to have a different attitude to hopes about post mortem events. It is rational to try to get rid of empty fears, since such fears are disturbing. By contrast, it is not necessarily rational to try to rid ourselves of hopes relating to post mortem events. An Epicurean can allow themselves to have such hopes since they need not be experienced as disturbing. And these hopes can motivate

3 Cicero On Moral Ends translated by Raphael Woolf (Cambridge 2001) p 60 .

4 There is, therefore, no need for me to take a stand in the recent debate between Woolf 2004 and Cooper 1998 as to whether we should take Epicureans to be committed to psychological hedonism, or only to a form of ethical hedonism. That said, I take Woolf's reading of the disputed passages in On Moral Ends to be more plausible than Cooper's. 
them to make provision for outcomes that can occur after their death.

My discussion will mention both Epicurus, and 'the Epicurean.' Cicero's own works provide a precedent for this: he talks not only of Epicurus, but also about ways in which those views might be developed by 'some Epicureans'. We need not suppose that Cicero always has in mind the views of particular, unnamed Epicurean philosophers (though in some cases he might). He also seems to be interested, as we might be, in the question of what someone might reasonably taken to be committed to by the adoption of key Epicurean views. ${ }^{6}$

Since 'the Epicurean' may nonetheless seem to be a somewhat shadowy figure, it may be helpful to say something about the constraints we should conform to in attributing views to him or her. First, we should take him or her to be committed to Epicurus' own views, to the extent that we can reconstruct them from our standard sources for them: Epicurus' own writings, the works of Lucretius and Philodemus, the testimonies of Diogenes Laertius and so on. ${ }^{7}$ Secondly we should take him or her not to be committed to anything obviously incompatible with those views. Thirdly, we should avoid attributing to him or her views a contemporary thinker might accept but which an inhabitant of the

5 In distinguishing here between what Epicurus held and what Epicureans more generally might have held I do not intend to suggest there is any doubt as to whether Epicurus accepted the experience constraint, nor to suggest that the problem that I am discussing would be anything other than problematic for him (for further discussion, see Section II below). The point is rather to insist on the potential interest of solutions to the problem which rely on views which are not directly attested to as being views of Epicurus himself. I thank an anonymous referee for Philosophical Papers encouraging me to clarify this.

6 There are at least two reasons for being interested in this. First, we might be interested in exploring the extent to which ancient views might still be live options for us (an exercise for which the work of such eminent commentators as Annas, Nussbaum, and Sorabji provides a precedent.) Secondly, the disciplined exercise of philosophical imagination is an important skill in reconstructing and understanding the views of named historical figures. In this context, it can be helpful to distinguish between what Epicurus actually said and how his view might have been developed in response to challenges which we know his views met. The distinction between Epicurus and 'the Epicurean' allows us to do so.

7 Philodemus is especially interesting here: as Konstan 2013 points out, he concedes that someone may feel some kind of emotional response to the thought of loved one's suffering hardship on account of one's death. See especially Philodemus On Death 25 2-10. 
ancient world would have good reason to deny. Finally we may, with caution, attribute to him or her views which contribute to the overall coherence and consistency of his or her position provided that they are consistent with these three constraints. ${ }^{8}$

\section{II: Cicero's Complaint}

Epicureans wrote wills. ${ }^{9}$ At least, Epicurus did: ${ }^{10}$ Diogenes Laertius and Cicero both tell us about it. ${ }^{11}$ (Cicero apparently thought it was rather ludicrous for Epicurus to have made provision in his will for his birthday to be celebrated after his death. $)^{12}$ Cicero's discussion of Epicurus' will can be found in On Moral Ends. He quotes, approvingly, Epicurus' last letter in which he discusses his impending death and urges his correspondent to take care of the children of Metrodorus. ${ }^{13}$ However, Cicero's praise for Epicurus is double-edged: while he applauds his fine moral character, he impugns his philosophical consistency, claiming that if Epicurus' view that the good is physical pleasure is correct, then Epicurus has no reason to be concerned for the children of Metrodorus;

\footnotetext{
8 In talking of 'the Epicurean' in this way, I take myself to be making explicit an approach that Warren shares. Precedents for imaginative reconstructions of Hellenistic philosophy include Nussbaum 1993 and Becker 1999 My approach has more in common with the former than the latter. Becker considers how someone attracted to a Stoic outlook might react to intellectual developments of the last two millennia-including developments that ancient Stoic might have been surprised by. I have no analogous concern, although I do consider what views Epicureans might have been able to accept, as consistent with their overall philosophical position.

9 See Philodemus On Death 39 10-15 for the suggestion that one advantage of a properly Epicurean attitude to death is that it makes the task of writing a will easier.

10 As did Diogenes of Oinoanda. Gordon 1996 suggests that by the time of the Second Sophistic, the philosopher's will was a recognisable philosophical genre. We might think Lucretius is adopting a more hard-nosed attitude, when he suggests that we should not now be moved by the thought that mourners will be sad after our death at On the Nature of Things III 906-12. We might think he is saying we shouldn't worry about this since we won't know about it when it happens. However, I think Lucretius' point is different: namely that the mourners will be behaving irrationally if they lament that we are undergoing something bad and so we shouldn't be concerned about them too much.

11 See Warren 2004 pp162-5 for a discussion of the reliability of these reports.

12 Cicero On Moral Ends translated by Raphael Woolf (Cambridge 2001) 2. 101-3. pp60-2.

13 Cicero On Moral Ends translated by Raphael Woolf (Cambridge 2001) 2.96 p58.
} 
and thus, presumably, no reason to write as he does. ${ }^{14}$

Since Epicurean views of friendship are a central concern of On Moral Ends, we might think that Cicero's discussion of wills is intended to support a claim about the instability of Epicurean conceptions of friendship or about the sort of relationships which Epicureans can sustain with other people. ${ }^{15}$ However, some time before the issue of Epicurus' will arises, Cicero signals fairly unambiguously that he is turning away from the discussion of friendship to address other topics. ${ }^{16}$ So we should consider what reasons Cicero has to think that will-writing in particular might pose problems for an Epicurean.

Cicero's discussion makes an unmistakeable allusion to a standard Epicurean argument for thinking that death is not an evil. ${ }^{17}$

Accustom yourself to thinking that death is nothing to us. For all good and bad is in perception; and death is the absence of perception. ${ }^{18}$

The conclusion of the argument is that death is neither good for us nor bad for us. It depends on the premiss that something can be good or bad for us only if it is something we can experience. Call the claim that something can be good or bad for us only if it is something we can experience the 'Experience Constraint'; call arguments which use the

14 Cicero repeatedly emphasises this: see for example the first sentence of On Moral Ends 2.100. (Cicero On Moral Ends translated by Raphael Woolf (Cambridge 2001) p59).

15 Friendship is clearly a key theme of the work. In Book I, Torquatus, the spokesman for Epicureanism, sets out a number of possible Epicurean approaches to the nature of friendship; in Book II, speaking in his own voice, Cicero undertakes to show the inadequacy both of Epicurus' own view, and some of the more sophisticated ways of developing it which Torquatus suggests. See Cicero On Moral Ends translated by Raphael Woolf (Cambridge 2001) 1. 65-8 pp23-4; and 2.78-85 pp 52-4.

16 The key passage is Cicero, M.T. On Moral Ends edited by Julia Annas and translated by Raphael Woolf (Cambridge: Cambridge University Press 2001) 2.85 p55: 'It has been conclusively proved that if pleasure is the standard by which all things are judged then there is no room for either virtue or friendship. There is nothing much to add. Still in case it should look like I have failed to respond to all of your arguments I shall make some comments on the rest of your exposition.'

17 Cicero, M.T. On Moral Ends edited by Julia Annas and translated by Raphael Woolf (Cambridge: Cambridge University Press 2001) 2.85 p 59.

18 The translation is based on those given by Warren Facing Death 2003 pp17, 19. 
'Experience Constraint' as a premiss to support the claim that we should not fear death 'Experience Arguments.'

The fact that Cicero alludes to an Experience Argument suggests that he sees the Experience Constraint, or something like it as the source of the Epicurean's problems. Cicero also makes it clear that Epicurus is writing from his deathbed. This makes salient something which is clearly relevant to Cicero's argument—namely that his will makes provision for certain things to happen after his death. However, Cicero's point will have some force against individuals other than Epicurus himself. For it is a standard feature of wills that they make provisions for certain things to happen or not to happen after one's death.

We might elaborate Cicero's point as follows. It is natural to take the person who is writing a will to be concerned to bring about certain events after their own death. But someone who accepts the Experience Constraint should not regard events that happen after their own death as being either good or bad for them. But if such events are neither good nor bad for one, one has no reason to try to bring them about.

If Cicero's point depends on the Experience Constraint in this way, then its cogency does not depend on the details of Epicurus' theory of pleasure or motivation. ${ }^{19}$ As we shall see, some Epicureans seem to have held that it is part of our natural psychological make-up to be concerned about the well-being of others. ${ }^{20}$ However, the sort of concern which we need to attribute to Epicureans to account for this material does not seem to be enough to dissolve the problems of the Epicurean will-writer without further ado.

19 See Mitsis, P. 1989 for discussion of the many subtleties of Epicurus' hedonism.

20 Cicero discusses a view of this sort in the Tusculan Disputations. See Tsouna 2007 for further discussion, including the suggestion that Cicero is drawing on Philodemus here. One reader suggested that this kind of view might be incompatible with psychological hedonism: if we are motivated by concern for the well-being of others then, one might think, one cannot be motivated solely by pleasure. This is a non-sequitur. If it is natural for us to take pleasure in the well-being of others, and this pleasure is something that can motivate us, then it can be true both that we are motivated by nothing but pleasure and that it is natural for us to be motivated by well-being of others. 
The problem outlined here will arise for any view which incorporates a commitment to the Experience Constraint. If the required form of motivation is not compatible with the Experience Constraint, we can disregard it: we are interested in the motivational possibilities of someone who does accept the Experience Constraint. If it is, then the existence of this form of motivation will not dissolve the problem. Since the problem arises as a consequence of accepting the Experience Constraint, supplementing that Experience Constraint with further claims about how we are motivated will not be enough to solve it.

\section{III: The Complaint Generalized}

We might disagree with Cicero's assessment of Epicurus' consistency. Perhaps, on his deathbed, Epicurus takes pleasure in the thought of Metrodorus' children being looked after. Perhaps writing as he does is an effective means towards sustaining this pleasure. If so, Epicurus' action makes sense even on his own terms. (We need not think that writing as he does is the only way in which Epicurus could sustain this pleasure: it is sufficient that it be one effective way. ${ }^{21}$ )

Does anything further need to be said ${ }^{22}$ James Warren has argued that this line of thought does not provide us with an adequate defense of Epicurean will-writing practice. As he says:

It is one thing to contemplate some future pleasurable event and take joy in it, but an altogether different thing to set about trying to ensure that this event will come about by constructing a legally binding document to be enacted after death. ${ }^{23}$

We can distinguish two related points here. First, 'the process of

21 This argument may rely on an overly naive conception of what an Epicurean would take pleasure to be. If so, Cicero's objection is harder to evade than I suggest, and the Epicurean in more, rather than less trouble. So be it: in what follows, I shall argue that even if Cicero's objection to Epicurus can be evaded, the fact it can be depends on features of Epicurus' particular situation which might not be shared by everyone who might consider themselves an adherent of his views.

22 I thank a referee for Philosophical Papers for raising this question forcefully.

23 Warren, J. 2004 p176. 
producing a will and of seeing that it is stored safely ... would add nothing to the bare activity of thinking pleasant thoughts about the future. If anything going to such trouble would appear to be a disturbance. ${ }^{24}$ Call this the 'Disturbance Consideration'. Secondly 'to write a will is to take an active hand in attempting to bring about certain events, and such an action surely implies some commitment to the importance of those events occurring. ${ }^{, 25}$ Call this the 'Commitment Consideration'.

Each of these considerations provides a reason for an Epicurean to avoid translating their pleasant thoughts about the future well-being of their beneficiaries into any non-trivial action aimed at bringing about that state of affairs. However, the considerations are connected: the less troublesome the actions are, the less commitment I seem to require. If the actions involved really are trivial, then it is not clear that any commitment is required at all: I might act on them, much as I might act on a mere a whim. ${ }^{26}$

This point is relevant to Epicurus' situation, as Cicero describes it. If Epicurus has already decided to write a letter from his deathbed, and if he takes pleasure in the thought of Metrodorus' children being provided for, then writing something about the provision he would like to see made for them might not require much effort. Perhaps, under the circumstances, it would take a concerted effort for him to avoid mentioning them.

Epicurus' situation is unusual. Writing a will typically involves more than making one's wishes known on one's deathbed. Will-writers often want to make provision for their dependents in ways that allow for the possibility of the will-writer's dying unexpectedly or in circumstances

\footnotetext{
24 Ibid p177.

25 Ibid p176.

26 If it costs me nothing to ensure that there is parsley in on the moon at some future date then the pleasure of contemplating this eventuality may be enough to make me do something to ensure that there is indeed parsley on the moon. It is only if I am required to do something difficult and dangerous, such as smuggling the parsley into a NASA facility that more seems to be required.
} 
which prevent them from making their wishes known at the moment of their death. This was as true in the ancient world as it is today. ${ }^{27}$ Furthermore, Epicurus was not a philosophical isolate. He was-and saw himself as-the founder of a philosophical school. ${ }^{28}$ So we should ask not only whether Epicurus' actions in writing his own will were consistent with his philosophical doctrines, but whether Epicureans more generally could have written wills without inconsistency.

We should not overstate how difficult a good Epicurean will find it to write a will . Many people might find thinking about the prospect of their own death unpleasant, and this puts them off will-making. Arguably, though, much of the unpleasantness that is involved thinking about one's own death in this way arises out of the fact that one is contemplating something which one fears or believes will be bad for one. ${ }^{29}$ A good Epicurean will not have this fear, or this belief, so they should not find the thought of their own death especially unpleasant. So we need not think that the Epicurean will find the making of wills any more difficult than many other complicated practical undertakings.

Still we should not entirely neglect the 'Disturbance Consideration': typically, the task of will-writing is non-trivial. Since the 'Disturbance Consideration' and the 'Commitment Consideration' are linked, the 'Commitment Consideration' will also need to be met. The 'Commitment Consideration' also has some independent bite: we need some explanation of why an Epicurean might actually write a will rather than merely think about the future prosperity of their children. A convincing answer to Warren should explain how an Epicurean might generate and sustain a motivation to do something non-trivially demanding in order to ensure the well-being of their friends and descendants after their death.

27 As Warren, J. 2004 pp176-9 points out. He also notes that in fact, Epicurus took nontrivial action to ensure that his will was carried out, such as making a public deposit of his will.

28 Cicero's mention of the fact that Epicurus made provision for his birthday to be celebrated may be a deliberate reminder of this.

29 As Philodemus points out at On Death 39 10-15. 


\section{IV: The Motivational Power of Hope}

I suggest that this refined version of the problem about Epicurean wills can be solved by focusing on what an Epicurean might hope for, rather than simply what they might contemplate with pleasure. ${ }^{30}$ To make this claim plausible, I need to defend three further claims. The first is that hope and belief are distinct states. The second is that it is often-though not always-pleasant to hope for certain kinds of outcome. ${ }^{31}$ The third is that someone who is motivated by pleasure will often have good reason to act in ways that will contribute to making their hope sustainable.

Hope and belief certainly seem to be distinct states. In particular hoping that $\mathrm{p}$ is not the same as believing that $\mathrm{p}$ will occur. Nor is it the same as believing that $\mathrm{p}$ will occur and that it is good that this should be so. These truths will be evident to many sports fans: one often hopes that one's team will be victorious, while believing, on the basis of prior experience, that it will not be. ${ }^{32}$ Furthermore, hoping for something is not the same as the contemplation of some possible future state of affairs conceived of as good. This is shown by the fact that I may, in a reverie, contemplate the possibility that England's opening bowlers take seven wickets in the opening session, and think that it would be very good if they were to do so while conceding that this is considerably more than I can, or even do hope for.

It does not follow that hope floats entirely free of thought and belief. One can only hope for things whose occurrence one takes to be

30 Is there an authentically Epicurean account of hope to draw on here? We might try to find one in On Ends I 57 and the Tusculan Disputations V 93 where Cicero puts into the mouth of Epicurean spokesmen the view that the thought or expectation of future pleasures is itself pleasant. However, I argue in this section that hope is not merely the pleasant thought of future pleasure. If it were, then for reasons which I have already rehearsed in Section III, and which (as we have seen) Warren, makes much of, it would be insufficient to motivate the Epicurean will-writer.

31 Note that I don't claim that it is always pleasant to hope for something. I shall say more about this in a moment.

32 These claims both depend on the fact that believing that $\mathrm{p}$ will occur is not a necessary condition for hoping that $\mathrm{p}$. They do not depend on the much less plausible claim that desiring that $\mathrm{p}$ is not a necessary condition for hoping that $\mathrm{p}$. I thank an anonymous referee for Philosophical Papers for encouraging me to clarify this point. 
epistemically possible. ${ }^{33}$ This is why hope is sometimes described as a 'forward-looking' state. It is unusual, but not impossible for us to hope for some event to have happened in the past. For example, not knowing how the day's play has turned out, I may turn on the evening news hoping that bad light stopped play early enough to forestall a collapse in the middle order. Such cases are unusual because, typically there are relatively few epistemic possibilities that remain open where the past is concerned.

The idea that hoping for something can be pleasant seems prima facie plausible. Of course, it is not always pleasant: when one hopes for an outcome which appears to be becoming vanishingly unlikely, either one's hope, or the combination of the hope with the belief that it is unlikely to be satisfied may take on an agonizing quality. (Fans of the England cricket team will need little reminder of this.)

Here is a conjecture compatible with these two pieces of data:

PLEASURE OF HOPE: It is particularly likely to be pleasant to hope for something when one takes it to be likely that what one hopes for will come about.

PLEASURE OF HOPE should be understood as a claim about the relative pleasurability of different instances of hoping for the same kind of thing. So it is not refuted by the observation that it is more pleasant to hope for a good dinner tonight, even when this is an unlikely prospect, than for the more certain prospect of my surviving till dinner time. Notice that it is a descriptive psychological claim, rather than a normative one. Its plausibility depends on the sorts of experience that people actually have. Furthermore the only things PLEASURE OF HOPE compares are the likelihoods of two states of hoping being

33 One referee suggested to me that Aristotle anticipates this point, and that Epicurus might have been aware of it. It's not clear to me that Aristotle does claim this in any discussion of hope that I have examined. But the plausibility of the point does not depend on its having an Aristotelian provenance. (I'm very grateful Richard Ashcroft, Jamie Dow and Nafsika Athanassoulis for help in tracking down passages where Aristotle might have said something similar, and for helpful discussion of those passages.) 
pleasurable: it makes no commitment to the comparability of different pleasures. It does not say that hoping for something which is certain is more pleasurable than hoping for something which is uncertain. ${ }^{34} 35$

Here's why PLEASURE OF HOPE seems plausible: sometimes, but not always the thought that what one is hoping for may not occur, may lead to an unpleasant state of anxiety. The more salient the possibility of this non-occurrence, the more likely it is that one will experience such anxiety. ${ }^{36}$

Someone might suggest that it is only pleasant to hope for something when one believes that the state of affairs which one hopes for will be a source of pleasure when it occurs. This seems considerably less plausible than PLEASURE OF HOPE. My hope that England will pull off an unlikely draw by batting out the final day may be accompanied by an awareness that if they do so, I will enjoy contemplating the response of my Australian office mate. (The hope may be none the less agonizing for all that.) Equally, I may be aware that the moment the match is finished, I will lose all interest in it without this detracting from the pleasure of hoping for a convincing win. ${ }^{37}$

A person's own actions can sometimes make a difference to whether what one hopes for will come about. If PLEASURE OF HOPE is correct, then someone who cares about pleasure will have a reason to act in such a way as to make it more likely that what they hope for will come about. (So for example, someone who is playing in rather than merely watching

34 I thank a different referee for Philosophical Papers for encouraging me to make this explicit.

35 This is fortunate since it is not clear that an orthodox Epicurean view has any room for the idea of quantifying pleasures. See Mitsis 1989 for discussion.

36 I assume that a state of pleasure mixed with anxiety is less pleasurable overall than a state of pleasure not mixed with anxiety; that the more anxious one is the more this will detract from the pleasure one feels; and that other things being equal, the more reason I have for being anxious, the more anxious I will be. These claims all seem compatible with standard Epicurean views about pleasure. I thank the referee mentioned in footnote 35 for urging this further clarification on me.

37 Nor do there seem to be any reasons grounded in Epicurean doctrine for taking this alternative to 'pleasure of hope' to be correct. See section VI for further discussion of related points. 
a match might be motivated to do what he could to increase the chances of victory in match where victory was to be hoped for.) Furthermore, in at least some cases one might expect the reasons that this pleasure gives might be enough to motivate one to undertake an otherwise complicated task. So PLEASURE OF HOPE suggests a response to both the Disturbance Consideration and the Commitment Consideration.

These points about the relationship between hope, pleasure, and motivation suggest that someone who is motivated by pleasure might plausibly be motivated to write a will because of the pleasure brought about by hoping for the prosperity of one's off-spring.

\section{V: Is the Account Compatible With Epicurean Psychology?}

Would a will-writer committed to Epicureanism be able to sustain the kind of motivation for will-writing which I have suggested? One reason for doubting this might be that in order to hope for the prosperity of one's children, one would have to believe that their prosperity after our own death would bring us pleasure. This would involve a belief about one's ability to have experiences after one's death which is incompatible with the Experience Constraint.

However, I have already argued in Section IV-from the case of hoping for victory in a cricket match in which I think I will lose interest once it is finished-against the idea that we can hope only for things which we think will bring us pleasure in the future. ${ }^{38}$ Might an Epicurean nonetheless be committed to the (mistaken) view that we can only hope for something which will be a source of future pleasure? Maybe: one might think that one can only hope for something which one believes will be good for oneself. If we combining this claim with the idea that the only way in which some state of affairs can be good is if it is a source of

38 One might object that these cases are unpersuasive because in them one has no influence over the outcome for which one is hoping (and they are, therefore, unlike the case of writing a will.) But it's not clear that the lack of causal influence makes a difference here: it is not clear that things would be different if I was a participant in the cricket match, or watching a TV talent contest where the winner was determined by the phone-in votes of watchers. 
pleasure at the time it occurs, it seems to follow that the Epicurean will only hope for things he or she believes will be a source of pleasure when it occurs.

This suggestion makes the connection between hope and belief tighter than is plausible for ordinary agents. It seems at least possible for me to hope for something which, on reflection, I am convinced does not matter much, if at all. As we have seen, sporting contests provide examples of cases where my hoping for a particular outcome (and my currently finding it pleasurable to do so) does not seem to rely on a conviction that the outcome would be good for me. Furthermore, reflecting on the fact that the outcome does not matter to me need not have a tendency either to undermine my hope. Nor, incidentally, need it prevent me from taking pleasure in this hope.

\section{VI: The Idea of an Empty Emotion}

Warren claims that an appeal to the motivational power of hope is not enough to dissolve the (apparent) problem of Epicurean will-writers. He thinks that even if an Epicurean's hope for the prosperity of their off-spring could generate the kinds of motivations which I have suggested, it is not the kind of emotion which a consistent Epicurean ought to feel. As far as the Epicurean is concerned it is, as he puts it, an 'empty' hope. ${ }^{39}$

Warren does not explore the notion of an emotional state's being empty to which he is appealing here in any detail. One might wonder whether it is genuinely Epicurean. ${ }^{40}$ Epicurus himself speaks of certain kinds of desires being empty, but his extant works do not seem to mention empty emotions. ${ }^{41}$ But as Julia Annas points out, in On Anger Philodemus distinguishes between 'empty' and 'natural' anger in ways that seem to parallel the distinction between empty and natural desires

39 Warren, J. 2004 p179.

40 As one referee for this journal did.

41 See, for example, Epistle to Menoeceus 127. 
in the Letter to Menoeceus. ${ }^{42}$ So there is some Epicurean precedent for the idea of an empty emotion. However, it is harder to explicate the notion in a way that supports Warren's complaint than one might initially suppose.

How might we understand the idea of an emotion's being empty? The following characterization seems initially to capture Warren's understanding of the notion:

EMPTY (B): An emotional state is empty if and only if that emotional state involves a false belief.

If the fear of death necessarily involves a belief that death is bad, this characterization will deliver the consequence that the fear of death is empty (at least, if we share the Epicurean belief that death is not bad). And if we take a hope for the prosperity of one's children after one's death to involve a belief that that prosperity will be good for the person hoping, this will be an empty hope.

However, it seems reasonable to think that a proper understanding of the notion of an emotion's being 'empty' should draw on the notion of a belief's being empty which we find in the Epistle to Menoeceus. In this text Epicurus tells us desires that are neither necessary nor natural are ones which arise out of an 'empty belief'. Annas notes that Epicurus does not say that all false beliefs are empty, and suggests that 'to be empty, a false belief has to be harmful.' ${ }^{43}$ So we might prefer the following formulation:

EMPTY (BE) E: An emotional state is empty if and only if that emotional state involves a harmful false belief-i.e., an empty belief.

Since Epicureans think the belief that our death is bad for us is not only false, but harmful, this still yields the result that fear of death is empty. However, it is less clear, on this conception of emptiness, that hope for the prosperity of one's off-spring is empty: to show this, we would to 
demonstrate that a belief that one's off-spring's prosperity would be a good thing is both false and harmful. Warren provides no argument that it must be harmful.

Here's an argument for that claim. The Epicurean sees freedom from the fear of death as a very important good. To attain this state she needs to think that post-mortem events or states of affairs cannot be good or bad for her. The belief that one's children's prosperity after one's death will be good for one conflicts with this belief. Resolving the conflict may lead to the Epicurean's losing the belief. This means she will miss out on an important good. She will, therefore be harmed.

\section{VII: Empty Emotions Reconsidered}

$\mathrm{B}$ and $\mathrm{BE}$ rely on a conception of the emotions on which beliefs and emotions are very closely linked. In Section IV I argued that hope need not be constitutively tied to belief in any way. If hopes need not involve beliefs neither B nor BE will entail that a hope for our children's prosperity after our death will be empty. Warren's argument against the Epicurean will-writer will fail.

Could an Epicurean hold that emotions need not involve belief? David Konstan has advanced a reading of Book III of De Rerum Natura which suggests they might. ${ }^{44}$ Konstan notes that much of this book is likely to seem like a fairly fruitless exercise in preaching to the converted, unless we hold both that it is difficult to free ourselves from the fear of death, and that Lucretius is aware of this. ${ }^{45}$ He suggests that as far as Lucretius is concerned one can accept the proposition that death is not an evil without integrating this insight into one's persona in such a way as to free one entirely from the fear of death, and that Book III is aimed at this further therapeutic goal. If Konstan's account of Lucretius is correct, we should attribute to Epicureans-or at least one Epicurean-a more complex view of the relationship between the belief

44 Konstan, 2008

45 Konstan, 2008 
that death is bad and the fear of death than we might otherwise be inclined to accept. ${ }^{46}$

What, then, might we say about the relationship between the fear of death and the belief that death is bad? Clearly any Epicurean needs to accept that the belief and the fear are related in a way which entails that lacking the belief means both that the fear is ungrounded, and that one is less likely to be assailed by the fear. Call these two claims the 'Epicurean Constraints on Fear'. The Epicurean constraints on fear are satisfied by the view that the belief and the fear are identical and the view that the belief is partially constitutive of the emotion. On either of these views under consideration, the fear of death should vanish once we no longer believe that death is an evil. ${ }^{47}$

However if the fear of death is rooted in us in a way that makes it difficult for us to extirpate even when we have the correct philosophical beliefs, and if we accept, in line with Konstan's suggestion, that Lucretius' poem reflects a sophisticated awareness of this fact, we might think that on the best interpretation of Epicurean views, the fear of death need not require a fully-fledged belief in the badness of death, but something less committal. ${ }^{48}$ Call the notion we need here 'assent.'

If we wish to allow Epicureans to hold that the fear of death need not involve a fully-fledged belief in the badness of death, then in order to preserve the claim that the fear of death is empty we need to revise our characterization of emptiness. What is needed is something like AE.

EMPTY (AE): An emotional state is empty if and only if that

46 There is no reason to think that Lucretius was eccentric, as an Epicurean, in holding such a view of the relationship between emotion and belief. David Sedley (Sedley 2003) has argued that there is good evidence for taking Lucretius to have been, on the whole, very conservative in his use of Epicurean views (he describes Lucretius as an 'Epicurean fundamentalist') .

47 Austin 2012 suggests some reasons for qualifying this view: she holds that an Epicurean may still fear violent and unexpected death. But this does not undermine the case I am making for arguing that on an Epicurean view, there is more to the fear of death than a belief in its badness.

48 For one such view see Stocker 1987. 
emotional state involves assent to a false claim, and assenting to this claim is harmful. ${ }^{49}$

$\mathrm{AE}$ preserves the claim that the fear of death is harmful. It also leaves open the possibility that a hope for the prosperity of our offspring may be empty, even if it involves no false belief. But it does not establish that such hopes are empty, since it leaves open the possibility that even if a hope of this sort involves assenting to a false claim, such assent need not be harmful.

$\mathrm{AE}$ enables us to distinguish between emotions which are empty and those which merely involve assent to a false claim but which may or may not be harmful. Call emotions in the second class 'false'; and call emotions which are false without being empty 'merely false'. So the class of false emotions divides into two: those which are merely false, and those which are empty. The problem of Epicurean Wills will be solved if we can show that a hope for the prosperity of one's children is merely false; to show there is a problem here, we would need to show that this hope is empty rather than merely false.

Some might think that the distinction that I have drawn between emotions that are empty and those that are merely false is unimportant. They might suppose that the fact that an emotion involves assent to a false claim is reason enough for the Epicurean to want to be rid of it. However, this seems wrong: what should matter from an Epicurean's point of view is whether the emotion is pleasant or painful. There is no obvious reason why a false emotion must be painful.

Notice that we do not need to suppose that all emotions which are based on accepting a false claim are painful to explain why we should wish to rid ourselves of the fear of death. This fear is unpleasant in itself; and, as Lucretius argues at the beginning of Book 3 of De Rerum Natura, it distorts our experience of life in many further respects: it makes us

49 For the purposes of this paper, the only kinds of emotion I discuss are hopes and fears. But other kinds of emotion, such as anger, might also be empty. See Annas 1989. 
cowardly, greedy, lustful, in ways which lead to further suffering. ${ }^{50}$ This, rather than simply the fact that it is based on accepting a false claim, gives us reason to avoid it. ${ }^{51}$

\section{VIII: Is Hope Harmful?}

If this is correct, then although a hope for the prosperity of one's offspring is false, we have yet to see any reason for taking it to be empty. Hope will often be pleasant to experience; and we have, as yet no reason to suppose that experiencing this hope should have deleterious effects on one's psychic constitution, as the fear of death does. So although it makes sense for an Epicurean to try to rid ourselves of the fear of death by dwelling on the fact that it cannot be an evil, it does not make the same sort of sense for her to try to rid ourselves of the hope that our children will prosper.

However, one might argue that even if hope for the prosperity of one's children does not involve a false belief, it will be unstable in a way that an Epicurean should find problematic. Sustaining such a hope is likely to give one at least a tendency to believe that at least one post mortem state of affairs is relevant to her well-being; and this tendency may lead to conflict with some of the beliefs which the Epicurean needs to have in order to sustain their equanimity in the face of death. Even if this conflict does not lead to the Epicurean's losing any of the beliefs that she needs to sustain, one might take it to itself constitute a kind of internal turmoil which an Epicurean has reason to avoid.

Whether this objection is compelling will depend to some extent on

50 Konstan, D. 2008 See also Nussbaum, M. 1993.

51 One might wonder why, on this view Epicureans think it is important to establish that the fear of death involves accepting a false claim. But this is easy to explain. It is only because the fear of death presupposes assent to the view that death is bad for us and this claim is intellectually unsustainable, that philosophy can free us from this fear. The fact that the fear of death involves accepting a false claim makes it possible to respond to it with philosophical arguments. But it does not show, by itself, that we are required to treat it in this way. It is only because the fear of death is unpleasant and that it brings other unpleasant things in its wake that we have reason to do so. 
one's overall picture of Epicurean psychology. If one thinks that an Epicurean will have no motivations at all other than a desire for pleasure, or if one thinks that they will try to extirpate any emotions which come into conflict with a desire for pleasure, then this objection might seem persuasive. However, not all Epicureans seem to have thought this way. It seems, for example, as though Philodemus thought that it is natural for us to be concerned about the well-being of those close to us; and that this fact should not present any embarrassment to an Epicurean. On Philodemus' account, this natural desire plays an important role in explaining how Epicureans can act in ways which seem consistent with the conventional morality of their society. ${ }^{52} 53$

Seeing the Epicurean's psychology in this way makes them seem more recognizably human than they might otherwise appear. It also suggests a response to the problem about instability. This is that an Epicurean might regard some kinds of desire for the well-being of our children to be an ineliminable part of our make-up. If this is correct, then it is not obvious that Epicureans ought to see it as something which we ought to try to suppress:attempting to do so might simply open us up to the possibility of disturbing internal conflicts.

We might start by observing that Philodemus at least seems to hold that the desire to provide for our dependents after our depth is deeply entrenched: as he puts it

leaving behind parents or children or a wife if they will be in dire straits on account of our death ... has of course a most natural sting, and this alone, or more than anything else stirs up emissions of tears in the sensible man. ${ }^{54}$

52 Tsouna, V. 2007 chapters 1-2.

53 This point suggests an answer to an objection made by several readers. The argument I have put forward might appear to suggest that an Epicurean might sustain a hope for posthumous fame-something which many Epicureans would think we should avoid. I think an Epicurean could argue that unlike the desire to see one's offspring flourish, a desire for the honours which might bring posthumous fame was unnatural. (We might also notice that Epicurus' desire to have his birthday commemorated, suggests that there is in any case some kind of tension to be seen in the Epicurean attitude to being honoured after one's death.)

54 Philodemus On Death 25 2-10 tr. W.B. Henry (Atlanta 2009). See also Armstrong 2003, 
Of course, a state could be deeply entrenched without ineliminable-it might instead be culturally established in just the way that Lucretius seems to think the fear of death is. However we can make a case for thinking that Philodemus at least takes the desire to fall into the category of desire that are natural and necessary.

Epicureans need not hold that a wise man will lack dependents. If we can believe Diogenes Laertius, Epicurus held that 'the wise man will marry and father children'. ${ }^{55}$ (And even if this were not true, the passage from Philodemus reminds us, even the wise person might have other dependents such as elderly parents.) This, of course tells us little about how we should relate to our children. Here we have less evidence of Epicurus' views. But Philodemus' reference to a 'natural sting' and to tears is suggestive. In the Principal Doctrines Epicurus distinguishes between desires that are natural and necessary, desires which are natural and unnecessary, and those which are neither natural nor necessary. ${ }^{56}$ He goes on to tell us that we can distinguish, among the latter two categories that 'those which do not lead to a feeling of pain when not fulfilled and about which there is an intense effort, these are produced by a groundless opinion. ${ }^{57}$

Which category does the desire for the well-being of one's children fall into? Let us put aside-at least for a moment-the suggestion that it is neither natural nor necessary, which seems to fit ill with the idea that the wise man will have children. (I shall return to it.) I take Philodemus'

2004.

55 Diogenes Laertius X 119 in The Epicurus Reader tr and ed Inwood B and Gerson, L.Indianapolis, Hackett. Chilton 1960—-followed by Nussbaum 1993—suggests emending the passage so as to make it say precisely the opposite, primarily in order to make Diogenes text consistent with the testimony of Epictetus and Seneca, but provides no convincing suggestions as to what kind of scribal error could have yielded the text we have. Since he does not, I am inclined to rely on the text rather than the testimony of philosophical opponents of Epicureanism.

56 Principal Doctrines XXIX in The Epicurus Reader tr and ed Inwood B and Gerson, L.Indianapolis, Hackett.

57 Principal Doctrines XXX in The Epicurus Reader tr and ed Inwood B and Gerson, L.Indianapolis, Hackett. 
comment, which I have quoted at length, to be giving us grounds for thinking that the desire falls into the natural and necessary category, rather than the natural and unnecessary one: by pointing out the fact that it produces a 'natural sting' and leads to tears in the sensible man he seems to be drawing our attention to the fact that it is a desire which leads to a feeling of pain when it is not fulfilled.

There is a natural objection. Epicurus holds that desires which are natural and necessary are easily fulfilled. One might think that a desire for the well-being of one's children is not easily satisfied. If so, then a consistent Epicurean might be forced to say that the desire seems is unnecessary. However this objection seems misplaced. How difficult it is for a desire for the well-being of one's children to be satisfied will depend on what one takes that well-being to consist in. Someone who thinks, as Epicurus does, that what is good for us is easily acquired, will presumably think that what is good for our children is easily acquired as well. ${ }^{58}$

Does an appeal to Philodemus' views here undercut the interest of my solution to Cicero's problem? Someone might think that once we take into account Philodemus views about the motivations an Epicurean might have the problem does not arise. If so, we do not need to appeal, as I have done, to the motivational power of hope in order to solve it. However I noted in Section II, this is not so: the problem arises for anyone who accepts the Experience Constraint, whatever their views about our motivation in pre-mortem situations. The appeal to hope provides the Epicurean with a form of motivation whose existence is compatible with a commitment to the Experience Constraint.

58 I have said little about what the content of an Epicurean will might be. However, Cicero's report tells us something interesting: Epicurus asks a friend to see to the wellbeing of the children of Metrodorus. Why do we know this detail? One possibility is that Epicurus' will was seen as (or even intended to be) exemplary. If so, it is presumably no accident that Epicurus asks for his dependents to be brought up by someone who is both an Epicurean and someone who is likely to be in a position to see that they can be part of an Epicurean community of friends. 


\section{VIII: Epicureans, Post Mortem Concern, and Us}

The sort of motivation which I have envisaged for the will-writing Epicurean might seem somewhat strange. It appears to involve hoping that one's children will flourish after one's death, and being motivated by this hope to do what one can to preserve one's hopeful state. As far as the Epicurean is concerned, this is rational because hope is, typically, pleasant.

This is not the sort of motivation that most will-writers have when they provide for their children. It might even suggest that Cicero's praise of the moral character (as opposed to the overt actions) of the Epicurean will-writer is misplaced. The will-writer seems to have-to adapt Bernard Williams' phrase—not one, but two thoughts too many. ${ }^{59}$ The child—or at least the non-Epicurean child of the Epicurean will-writer-might hope that their parents' will-writing would be motivated by a concern for their well-being; not by the desire to preserve themselves in a hopeful state, nor by thoughts of how pleasant that state might be.

It is not obvious whether an Epicurean should take this objection seriously. Epicurus would surely have expected that someone who wholeheartedly accepts Epicurean principles would find their motivations-and to the extent that characteristic patterns of motivation are part of character, also their character-altered; and, no doubt, in ways that not all of his contemporaries would have found admirable. Epicureans were not attempting to provide a rational reconstruction of the common-sense morality of their day: they would presumably have seen that common-sense morality as being radically mistaken in various respects.

Should we should take the objection seriously? It may not be clear what is being asked. We are not Epicureans; we are not committed to anything like the common-sense morality of any of the social milieux in which ancient Epicureanism flourished; and it is not immediately clear what common-sense intuitions about will-writing we might expect a

59 Williams 1981. 
plausible account of the practice to vindicate.

However part of my motivation for addressing the apparently narrow scholarly problem of explaining how an Epicurean philosopher might consistently have sustained the sort of motivation which one might take to be necessary for writing a will has been to see what the answer to this question might have to tell us about the sorts of questions which might arise for people alive today.

Many of us face problems analogous to the problem of the Epicurean will-writer: we hold that there is no post mortem experience, and that the Epicurean principle that what we do not experience can be nothing to us is at least plausible. We are also concerned with a variety of states of affairs that might occur after our death-whether these be local matters, such as the fate of those close to us who will survive our death, or larger, more political concerns, such as the way in which our actions might affect the climate and environment that future generations may face after our deaths.

In thinking about these problems, we have theoretical options which are not available to the Epicurean will-writer. We might choose to accept-as Aristotle did-a conception of happiness or well-being on which our well-being can be affected by events which happen after our death. ${ }^{60}$ Or we might argue-though perhaps no ancient philosopher could have done so-that there are considerations which ought to motivate us even if they have no impact on our well-being. There is no simple knock-down argument against either of these views. Still, it is worth exploring the viability of a response to the problem which does not depend on either of them. For, even if every possible objection to those views turns out to be mistaken, at least some of those objections are likely to continue to seem persuasive.

I have argued that Epicureans could reasonably have written wills, provided that it was natural for them to hope for the well-being of their

60 Aristotle Nicomachean Ethics I. 11 in The Basic Works of Aristotle translated by Richard McKeon, (New York, Random House 1941) pp 947-8. 
legatees; that their will-writing was something which was necessary to sustain such hopes; and that insofar as these hopes were pleasant, there was no reason for them to attempt to suppress them. I have also argued that these claims are at least rationally defensible.

For someone who faces the contemporary analogue of the Epicurean problems, the analogous provisos would appear to be that it is natural for us to hope for certain kinds of post mortem states of affairs; that certain actions should be required of us to sustain those hopes; and that those hopes should be ones that we have reason to sustain. If so, then there is, of course, much further philosophical work to be done. The interesting question is whether the two thoughts which one might take to be too many in this contexts are ones which have analogues which would disqualify the kind of solution I have suggested to the Epicurean problem from being a solution to something which is a problem for us. ${ }^{61}$

\author{
Bilkent University \\ billwringesemail@gmail.com
}

\title{
References
}

Annas, J. 'Epicurean Emotions' Greek, Roman and Byzantine Studies 30 (1989) pp. 145-64.

Annas, J. Hellenistic Philosophy of Mind University of California Press, Berkeley. 1992 .

Aristotle The Basic Works of Aristotle translated by Richard McKeon, (New York, Random House 1941).

61 I am grateful to Sandrine Berges, Sandy Berkovski, Lars Vinx and other audience members at a work-in-progress seminar in the philosophy department at Bilkent University for helpful discussion; to Richard Ashcroft, Jamie Dow, and Nafsika Athanassoulis for advice on tracking down Aristotle's views about hope; and to three referees for this journal, whose extensive written comments enabled me to improve the paper in a number of respects. I've also benefited from comments from a number of readers who I am not able to identify, some of whose inaccurate speculations as to my educational background and knowledge of Greek provided much amusement when I was working on earlier drafts. 
Armstrong, D. 'Philodemus, the Herculaneum Papyri and the Therapy of Fear' in Epicurus: His Continuing Influence and Contemporary Relevance ed Dane R. Gordon and David B. Suits (Rochester NY; RIT Cary Graphic Arts Press, 2003).

Armstrong, D. "Be Angry and Sin Not": Philodemus versus the Stoics; on Natural Bites and Natural Emotions' in Passions and Moral Progress in GrecoRoman Thought edited by Fitzgerald, J.T. (Leiden, Brill 2004).

Annas, J. The Morality of Happiness (New York; Oxford University Press 1993).

Austin, E. (2012). Epicurus and the Politics of Fearing Death. Apeiron 45 (2):109129.

Becker, L. A New Stoicism (Princeton; Princeton University Press 1999).

Chilton, C. 'Did Epicurus Approve of Marriage? A Study of Diogenes Laertius X, 119.' Phronesis 5 (1960) pp. 71-74.

Cooper, J. Reason and Emotion (Princeton; Princeton University Press 1998).

Cicero, M.T. On Moral Ends edited by Julia Annas and translated by Raphael Woolf (Cambridge; Cambridge University Press 2001).

Cicero, M.T. Tusculan Disputations translated by J.E. King (Cambridge; Harvard University Press 1996).

Gordon, P. Epicurus in Lycia: The Second-Century World of Diogenes of Oinoanda (Ann Arbor, University of Michigan Press 1996).

Konstan, D. A Life Worthy of the Gods: The Materialist Psychology of Epicurus (New York; Parmenides Publishing 2008).

Konstan, D. 'Lucretius and the Epicurean Attitude towards Grief' in Lucretius: Poetry, Philosophy, Science edited by Lehoux, D., Morrison, A. and Sharrock, A. (Oxford, Oxford University Press 2013).

Lucretius, T.C. On the Nature of Things translated by Martin.Ferguson Smith (Indianapolis; Hackett 2001).

Mitsis, P. Epicurus' Ethical Theory: The Pleasures of Invulnerability (Ithaca, Cornell University Press 1989).

Nussbaum, M. The Therapy of Desire (Princeton, Princeton University Press 1993).

Philodemus On Death translated by W.B.Henry, Society of Biblical Literature 2009.

Sedley, D. Lucretius and the Transformation of Greek Wisdom (Cambridge, 
Cambridge University Press 2003).

Sorabji, R. Emotion and Peace of Mind (Oxford, Oxford University Press 2001).

Stocker, M. 'Emotional Thoughts' American Philosophical Quarterly 24 (1987) no 1: 59-69.

Tsouna, V. The Ethics of Philodemus (Oxford, Oxford University Press 2007).

Warren, J. Facing Death: Epicurus and His Critics (Cambridge; Cambridge University Press 2004).

Williams B. 'Persons, Character and Morality' in Moral Luck (Cambridge, Cambridge University Press 1981).

Woolf, R. 'What Kind of Hedonist Was Epicurus?' Phronesis 49 (2004) no 4: 303322. 